\section{Rutherford Memorial Appointments}

UNDER the terms of the scheme to commemorate the late Lord Rutherford of Nelson the following appointments have been made by the Council of the Royal Society. Sir Lawrence Bragg has been appointed Rutherford Memorial Lecturer for 1960, to deliver the lecture in New Zealand. Mr. D. J. Tritton, now working at the Cavendish Laboratory, Cambridge, has been appointed Rutherford Scholar for 1959 for three years, to investigate the relationship between the manner of production of turbulence in a fluid flow and the large eddy structure of that turbulence, at the department of aeronautical engineering, Indian Institute of Science, Bangalore.

\section{Canadian National Research Council Scholarships for 1959-60}

The National Research Council of Canada has granted 399 scholarships for 1959-60, with a total value of 844,600 dollars. Three hundred and fortyone of these scholarships are for graduate work at Canadian universities. Awards for study abroad include thirty-three special scholarships, to be held in the following countries: eighteen in the United Kingdom; fourteen in the United States ; and one in France. Twenty-five postdoctorate overseas fellowships have been granted for work in the following countries: nineteen in the United Kingdom; five in France; and one in the Netherlands.

\section{University News :}

California

A Department of Virology has been established in the University of California at Berkeley. Chairman of the new Department is Dr. Wendell M. Stanley, Nobel laureate and director of the Virus Laboratory. Eight faculty members, drawn from the Virus Laboratory, now comprise the staff of the Department. Starting in September 1959, lecture courses will be offered to graduate and advanced undergraduate students, to be followed later by a comprehensive laboratory course. Additional instruction will be offered, mostly at graduate level, in the form of special study courses, seminars, and research projects.

lbadan

Prof. F. W. Sansome, professor of botany in University College, Ibadan, Nigeria, has been appointed professor of botany in the University College of Ghana, Achimota. He is to be succeeded at Ibadan by Dr. E. Njoku, at present senior lecturer in the College.

London

THE new Sir John Atkins Laboratories, of which Sir John Atkins laid the foundation stone on June 24, will enable important and urgently needed developments to take place at Queen Elizabeth College, London. The College is the only institution in Britain that provides courses leading to a degree in nutrition (B.Se. Nutrition, London) and shares with the University of Bristol the distinction of preparing students for the only degrees in household seience (B.Sc. Household Science, London). In the new buildings, which will house the Departments of Bacteriology, Biology and Nutrition, more students can be accommodated and much more research in these subjects can be undertaken. More accommoda- tion for teaching and research will also be available for the five other science departments which will expand in the present buildings.

Michigan

Dr. WRAY SMITH has been appointed assistant director of the Willow Run Laboratories. He will continue to be responsible to the director and associate director of the Willow Run Laboratories for the direction of the administrative staffs of the laboratories and for assisting the director and associate director in formulating and implementing administrative policies and procedures. He has been on the Willow Run Laboratories staff since 1954 and has been administrative associate since early in 1958.

Prof. Louis J. Cutrona, professor of electrical engineering in the University of Michigan, has been appointed head of the largest of the several labora. tories within Willow Run. The Radar Laboratory is involved in major programmes in the field of airborne and ground-based radars with support through Project Michigan, the U.S. Air Force and the Advanced Research Projects Agency.

\section{Announcements}

Ax the first commencement on June 18, the honorary degree of D.Sc. was conferred on Dr. Peyton Rous and on Dr. Herbert S. Gasser for their contributions to the development of the Institute and the attainment of its high standards in research and scholarship.

Sir Hugh Beaver was recently elected president of the Royal Statistical Society for the ensuing year. Mr. B. Benjamin, Miss J. I. Douglas and Dr. P. Armitage were re-elected honorary secretaries, and Mr. R. F. Fowler was re-elected honorary treasurer.

Dr. F. Kenneth Brasten, former president of the University of Dallas, has joined Texas Instruments Ineorporated as administrative director of its Central Research Laboratory.

Dr. Margaret Hannah has been awardod the Warner Medal which is given by the Textile Institute for outstanding work in textile science and technology. Dr. Hannah was formerly a lecturer in textile engineering in the University of Leeds.

Trxe ninth Annual Instrument Symposium and Research Equipment Exhibit will be held during September 28-October 1 at the National Institutes of Health, Bethesda, Maryland. Further information can be obtained from James B. Davis at the above address.

The third conference on Analytical Chemistry in Nuclear Reaction Technology will be held in Gatlinburg, Tennessee, during October 26-28. Further information can be obtained from C. D. Susano, Oak Ridge National Laboratory, P.O. Box Y, Oak Ridge, Tennessee.

Erratum. In the "News and Views" item entitled "Ultrasonic Vibrations at 10,000 Megacycles", published in Nature of June 6, p. 1570, the work referred to is being carried out by Dr. E. H. Jacobsen, a member of the General Electric Company Research Laboratory, Schenectady, New York, and not by Dr. E. H. Jackson, as printed. 